\title{
Patient-Derived Xenograft Models in Urological Malignancies: Urothelial Cell Carcinoma and Renal Cell Carcinoma
}

\author{
Andrew T. Tracey ${ }^{1}$, Katie S. Murray ${ }^{2}{ }^{\mathbb{D}}$, Jonathan A. Coleman ${ }^{1}$ and Kwanghee Kim ${ }^{3, *}$ \\ 1 Urology Service, Department of Surgery, Memorial Sloan Kettering Cancer Center, \\ New York, NY 10065, USA; traceya@mskcc.org (A.T.T.); colemanj@mskcc.org (J.A.C.) \\ 2 Department of Surgery, Division of Urology, University of Missouri, Columbia, MO 65211, USA; \\ murrayks@gmail.com \\ 3 Department of Surgery, Memorial Sloan Kettering Cancer Center, New York, NY 10065, USA \\ * Correspondence: kimk1@mskcc.org; Tel.: +1-646-422-4432
}

Received: 19 January 2020; Accepted: 10 February 2020; Published: 13 February 2020

\begin{abstract}
The engraftment of human tumor tissues into immunodeficient host mice to generate patient-derived xenograft (PDX) models has become increasingly utilized for many types of cancers. By capturing the unique genomic and molecular properties of the parental tumor, PDX models enable analysis of patient-specific clinical responses. PDX models are an important platform to address the contribution of inter-tumoral heterogeneity to therapeutic sensitivity, tumor evolution, and the mechanisms of treatment resistance. With the increasingly important role played by targeted therapies in urological malignancies, the establishment of representative PDX models can contribute to improved facilitation and adoption of precision medicine. In this review of the evolving role of the PDX in urothelial cancer and kidney cancer, we discuss the essential elements of successful graft development, effective translational application, and future directions for clinical models.
\end{abstract}

Keywords: xenograft; renal cell carcinoma; urothelial cell carcinoma; patient-derived xenograft; urologic oncology

\section{Introduction}

The increasingly recognized complexity of human cancers and the heterogeneity of malignant tumor cells have posed a major challenge to development of effective therapies in urologic oncology. Traditional cancer cell lines, the backbone of pre-clinical oncologic research, often fail to adequately address many of these conundrums, lacking the ability to faithfully recapitulate cancer treatment response and malignant progression. The engraftment of patient solid tumor tissues into immunodeficient host mice to generate patient-derived xenograft (PDX) models has been shown to provide a more valuable predictive paradigm in today's era of personalized medicine and targeted therapies [1,2]. In principle, such PDX models should capture the unique genomic and molecular properties of the parental patient tumor and enable analysis of patient-specific clinical responses to therapy [3].

The advent of PDX techniques date back to 1969, when a human colon cancer tumor was grafted into an athymic nude mouse [4]. However, the first reports of utilization of this technique on urologic malignancies, namely urothelial carcinoma and renal cell carcinoma (RCC), were published in the 1970 's [5-7]. Since this time, PDX models have increased in their prevalence, serving to improve our understanding of both bladder and kidney cancers.

In what has been termed the age of "precision medicine," there is increasingly recognized heterogeneity between tumors that contributes to variation in therapeutic responses. PDX models can play a role in assessing susceptibility to both traditional chemotherapeutic agents, as well as novel 
targeted treatments that exploit the biology of a patient's unique tumor type. Creation of a xenograft model involves transfer of tumor fragments from a live patient's primary tumor or metastatic site into immune compromised mouse strains, most frequently NOD (non-obese diabetic) scid (severe combined immunodeficient) or NOD.Cg-Prkdc ${ }^{\text {scid }} \mathrm{Il}_{2} \mathrm{rg}^{\mathrm{tm} 1 \mathrm{Wjl}} / \mathrm{SzJ}$ strains (NOD scid gamma, NSG). When utilized for research purposes, many studies have shown that these tumorgrafts retain the parental tumor histology, cellular structure, and genomic characteristics. At present, the cost of this process, variability in graft success rates, and the time required to establish the xenograft have been a barrier to the widespread implementation in clinical practice. While the oncology community remains optimistic that PDX models will one day serve as "mouse avatars," providing patients and their clinicians with real-time information on tumor therapy response and tumor evolution, PDX models are not yet capable of serving as a decision-making tool. However, their role in the study of kidney and bladder cancers continues to expand, improving our understanding of disease biology.

Kidney cancer and bladder cancer have a major impact on the American public, together accounting for more than 150,000 new cases annually, and comprising 8.8\% of new cancer diagnoses in 2019 . Moreover, there will be a total of 33,420 patients who succumb to these diseases, accounting for $5.5 \%$ of all cancer-related deaths [8]. Though urothelial cell carcinoma and renal cell carcinoma are morphologically and histologically distinct malignancies, there are overlapping treatment paradigms in the advanced setting that make them both ideal tumors to study using PDX models. This is particularly true with the advent of next-generation sequencing and the revolution of tumor characterization in the "omics" era.

Urothelial carcinoma, which originates in the lining of the bladder and upper tract, is the sixth most common malignancy in the United States. However, it has an outsized impact on the US healthcare system, with the highest lifetime treatment cost per case of all cancers [9]. Though effective endoscopic management and intravesical therapies portend a relatively good prognosis for non-muscle invasive bladder cancer, the survival trends for muscle-invasive and metastatic disease have stagnated for the past 30 years despite increasing utilization of neoadjuvant chemotherapy and advancements in surgical technique $[10,11]$. Though there have been encouraging results from clinical trials involving newly developed immune-checkpoint inhibitors, cisplatin-based chemotherapy remains the mainstay of treatment in both the neoadjuvant and metastatic setting. Chemotherapy portends a relatively modest $5-7 \%$ overall survival benefit in the neoadjuvant setting, and the overall response rate is well below $50 \%$ in metastatic $[12,13]$. These data taken together underscore the need to develop better treatments, and more importantly the need to predict individual patient therapeutic response.

Kidney cancer follows closely behind urothelial cancer as the eighth most common malignancy in the US. Again, like urothelial carcinoma, clinically localized stage I and II kidney cancers can be treated with extirpative management resulting in excellent survival. Unfortunately, treatment of locally advanced or systemic disease presents a significant challenge for clinicians, with a dismal $12 \%$ survival at 5 years in the metastatic setting [14]. As in urothelial carcinoma, immune-checkpoint blockade plays a growing role in treatment of advanced RCC. However, there are numerous targeted therapies that are currently employed in clinical practice or in development that require further investigation to delineate their role in treatment regimens. PDX models have the potential to define treatment modality and sequencing in both the localized and advanced settings for kidney and bladder cancers.

\section{Experimental Procedures in PDX Engraftment}

\subsection{Host Animal Selection}

Selection of immunocompromised mice for tumor engraftment plays an important role in the establishment of the PDX model. Researchers have developed successful models in four different types of mouse hosts: nude mice, scid mice, NOD (non-obese diabetic) scid mice, and mouse strains bearing targeted immunocompromising mutations in $I l 2 \mathrm{rg}$. 
Nude mice are one of the earliest mouse strains established for human cancer research, thus named for their lack of fur. They are athymic, and their reduction in T cell production inhibits the adaptive immune response. However, their intact innate immunity can limit utility for human tumor grafting, particularly in less aggressive, slower growing tumor types, or in more immunogenic malignancies such as RCC and urothelial carcinoma [15]. The scid mice are a strain with severe combined immunodeficiency developed in C.B17 mice, which prevents the development of mature T cells and B cells. This contributed to improved engraftment efficiencies over nude mice [16]. While nude mice and scid mice both lack adaptive immunity, their intact innate immunity and active natural killer (NK) cells can contribute to rejection of xenograft implantation and prevent tumor growth.

These issues with engraftment take-rate led to the development of more severely immunocompromised mice with impaired innate immunity, including NOD scid mice [17]. The lack of both innate and humoral immunity in these strains yields higher take-rates than nude or standard scid mouse strains, but these deficiencies lead to a shortened lifespan due to development of thymic lymphomas by 8-9 months of age, particularly in female mice. As such, careful monitoring of the animals for signs of spontaneous lymphoma development, including panting, bulged eyes, and splenic enlargement, is essential as thymic lymphoma can influence experimental results [18].

Finally, targeted mutations in Il2rg led to the development of NSG (NOD.Cg-Prkdc $c^{\mathrm{scid}} / 12 \mathrm{rg}^{\mathrm{tm} 1 \mathrm{Wjl}_{\mathrm{jl}}}$ ),

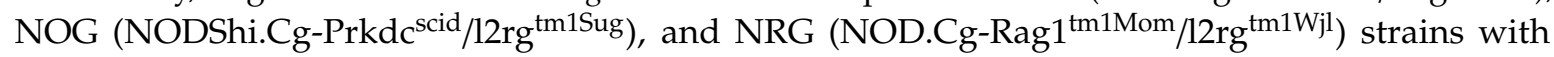
targeted deficiencies in $\mathrm{B}$ cells, $\mathrm{T}$ cells, and NK cells. The deficiency in both the innate and adaptive immune systems allows for acceptably high take rates for human tissue engraftment [19]. Though initially thought to be resistant to the spontaneous thymic lymphomas that limit the lifespan of NOD scid mice, various labs have reported low rates of both thymic lymphomas and other non-human tumors following engraftment. Development of spontaneous thymic lymphomas has been reported in up to $15 \%$ of C.B17 scid mice and $67 \%$ of NOD-scid mice, while the incidence of spontaneous lymphoma is much lower in $I l 2 \mathrm{rg}$-deficient mouse models (NSG/NOG/NRG), with reported rates of $0.7 \%$ in NSG and NOG mice $[15,20-22]$.

\subsection{Tumor Specimen Collection and Preservation}

Samples of primary and metastatic tumors sites that are resected surgically or biopsied are used for grafting. For RCC, sufficient tumor tissue can be taken at the time of radical or partial nephrectomy. After pathologic review, regions of the tumor specimen with viable (non-necrotic) malignant cells are brought to the lab for implantation. Unreliable tissue yields from tumor core biopsies make this a poor alternative. For bladder cancer, it is possible to establish grafts using tumor samples from both transurethral biopsy/resection specimens, as well as from radical or partial cystectomy specimens. Again, pathological confirmation by a genitourinary pathologist is a necessity, as chemotherapeutic treatment response or cautery artifact can affect tumor engraftment. Once specimens are removed from the patient, they should be placed in Roswell Park Memorial Institute (RPMI) medium or phosphate-buffered saline (PBS) solution and placed directly on ice. It is essential to minimize the time interval between excision of the tumor from the patient and engraftment in a mouse host in order to maximize tumor viability. In the case of renal cell carcinoma, when orthotopic engraftment into renal subcapsular space is planned, tissue slice grafts cut to $300 \mathrm{uM}$ can be effectively used. Early models using this technique demonstrated ease of engraftment, and metastatic potential of the tumors. This approach also allows for generation of larger first-generation cohorts in the setting of limited tumor tissue [23].

While PDX models are often maintained through serial passaging in mice, this can be costly and labor intensive. With limited resources, it is often necessary to freeze early generation xenografts for potential expansion at a later date. Cryopreservation with subsequent reanimation is an efficient and effective way to select tumors for PDX. Samples can be preserved at $-80{ }^{\circ} \mathrm{C}$ in cryoprotectant $10 \%$ DMSO (dimethyl sulfoxide) media with 10\% fetal bovine serum and RPMI solution. Alternatively, preservation can be done in a specialized cryopreservative (i.e., Cryostor CS10-BioLife Solutions, 
Oswego, NY, USA), which has been shown to improve tumor reanimation engraftment efficiency [24,25]. Cryopreservation also gives researchers the opportunity to select tumors for PDX establishment or expansion based on clinical data that may not be known at the time of tissue acquisition.

\subsection{Heterotopic Subcutaneous Engraftment}

Once tumor tissue is adequately prepared for engraftment, host mice should be anesthetized using inhaled isoflurane. The area of fur overlying the anticipated incision should be shaved and sterilized using proper technique of betadine and alcohol. A small $(<1 \mathrm{~cm})$ skin incision is made in the flank or midback of the animal (Figure 1). A small subcutaneous space is developed bluntly using a surgical instrument. Care is taken not to damage the muscle. A single piece of tumor between $10-20 \mathrm{~mm}^{3}$ should be implanted into this incision; bilateral engraftment can be achieved through the same incision if desired. Bilateral engraftment can be a more cost-effective way to increase tumor yield. Wound clips or surgical suture should be used to close the incision once graft is placed. Institutional standards should be used to monitor the mice after surgical implantation. Caliper measurement devices are used to measure tumor size in 3 dimensions at least bi-weekly, though more frequent measuring is necessary if tumor growth is rapid. Peri-procedural collaborative involvement of the institutional veterinary staff is essential to ensure appropriate care and optimal results. When indicated by the veterinarians, mice may be started on prophylactic amoxicillin or trimethoprim-sulfamethoxazole in their food, or enrofloxacin (Baytril) in drinking water to prevent graft or surgical site infection. In such cases, the antibiotic is typically continued until the host animal is euthanized.
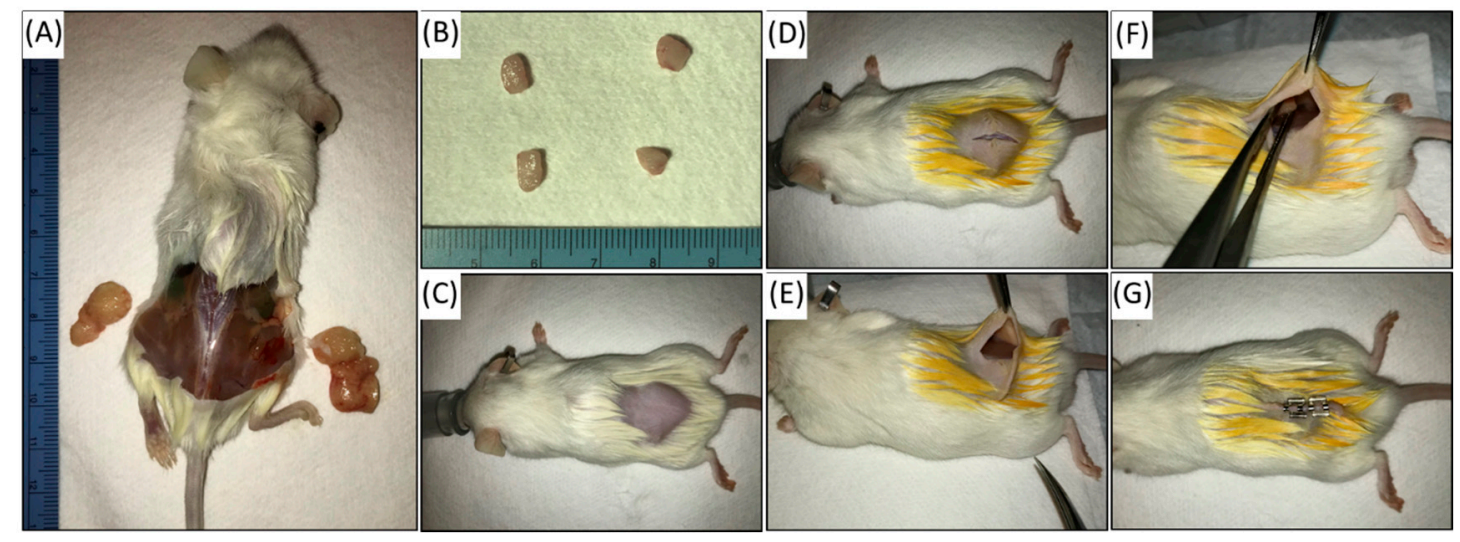

Figure 1. Passaging of patient-derived xenograft (PDX): NSG mice are euthanized once tumors reach approximately $1.5 \mathrm{~cm}$ as measured by Vernier caliper (A). Tumors are explanted and divided into $5 \mathrm{~mm}$ pieces for engraftment (B). Additional tumor specimen is collected at every passage for formalin fixation and paraffin embedding to confirm faithful maintenance of malignant histology. The new host NSG mouse at 6-8 weeks is anesthetized and prepped for grafting $(\mathbf{C})$. The hind region is shaved and cleaned with alcohol and betadine. A $1 \mathrm{~cm}$ midline incision allows for bilateral implantation, if desired $(\mathbf{D}, \mathbf{E})$. Tumor specimen is placed in subcutaneous pouch overlying the muscle (F). Matrigel can be used to keep tumor in position. Skin is closed, and mouse is started on amoxicillin for infection prophylaxis (G).

\subsection{Orthotopic Engraftment}

It has been suggested that orthotopic grafting, namely implantation of tumor tissue into the renal subcapsular space for RCC or into the bladder wall or lumen for urothelial cancer, may better simulate the clinical disease course with development of distant metastases [26]. While more challenging technically than subcutaneous implantation, renal subcapsular implantation takes advantage of the vascularity of the kidney and has been associated with higher engraftment rates, while potentially allowing for clinically relevant metastatic models to be created [18]. The approach involves a 5-7 mm incision parallel to and below the 13th rib. After dissecting through subcutaneous tissue and muscle, 
the kidney is pushed out through the incision [27]. Tumor cells can be put into a solution with Matrigel and injected into the renal subcapsular space using a small Hamilton needle, or a small incision in the capsule can be made and the donor tumor fragment can be placed under the capsule sheath.

Technical challenges specific to the murine bladder have limited the development of orthotopic PDX models, with subcutaneous heterotopic implantation in the midback or flank reported in most published studies to date. However, various methods of orthotopic bladder PDX model creation have been described in the literature. One such method utilizes a small laparotomy incision to exteriorize the bladder, followed by drainage and direct injection of tumor cells into the bladder lumen [28]. Alternatively, transurethral injection of cells into the bladder lumen has been described following an electrical or chemical perturbation of the bladder lumen, though inconsistent take-rates have largely limited this approach to patient-derived cell lines rather than bulk tumor implantation [29,30].

\subsection{Advanced/Metastatic Disease Models}

While evaluation of local tumor characteristics is important to guide therapeutic innovation, most patients eventually succumb to RCC and urothelial cancer due to metastatic spread. One of the major criticisms of PDX models, particularly heterotopic xenografts with subcutaneous implantation, is the lack of spontaneous metastases. Few metastatic models have been reported in bladder, though Tatum et al. described using BL0293, a patient-derived muscle-invasive bladder cancer PDX developed by Jackson Laboratory and University of California-Davis, as a reliable model for spontaneous and post-excisional metastatic disease to the liver. Notably, this model metastasized using a subcutaneous heterotopic implantation method [31]. In their cohort of orthotopic RCC xenografts, Thong et al. identified metastases to a few clinically relevant sites, including lung, liver, and bone, mimicking the clinical course of the patients from whom the tumors were derived [23].

A notable challenge in establishing a metastatic PDX model is non-invasive tracking of tumor spread. While cell-line derived xenografts can incorporate molecular markers such as luciferase to monitor for metastatic spread, this cannot be done with patient-derived tumor xenografts. Metastases can be identified on necropsy, but various imaging modalities allow for surveillance in survival studies. The primary tumor is monitored with calipers in the subcutaneous model, and orthotopic models can utilize ultrasound of the bladder or kidney, though image acquisition and interpretation are largely operator dependent. In their metastatic tumor model, Tatum et al. found that non-contrast T2-weighted MRI was the most effective way to accurately characterize metastatic burden in their mice [31].

\subsection{Success Rates of Engraftment}

Generally, successful engraftment rates depend on a combination of host animal selection and tumor histology. High grade and advance-stage tumors are typically associated with an improved take-rate, owing to aggressive characteristics of the tumor cells. The same characteristics that allow a tumor to seed distant metastatic sites in humans appear to also allow for successful engraftment in mouse hosts. The faster growth rate of aggressive tumors also allows for more rapid expansion and serial passaging [19]. In a study of 94 orthotopic RCC tumor graft samples, Sivavand et al. found an engraftment success rate of $80 \%$ when samples are derived from metastases, as opposed to a $14 \%$ take-rate when grafting from the primary tumor [32]. Their work suggested that a stable engraftment of a clinically localized tumor is correlated with metastatic potential and a shorter survival in the donor patient [32]. Slower growing tumors can be a challenge in establishment of PDX models. Use of Matrigel with growth factor for low-proliferation tumors may improve rate, though this remains a significant challenge.

Engraftment rates in renal cell carcinoma can vary widely depending on the site of engraftment. Orthotopic renal subcapsular engraftment of tumor into the murine kidney has been shown to recapitulate tumor growth characteristics and metastatic potential [23,33], but importantly this approach has also been shown to yield higher rates of successful tumor engraftment [19]. 
When the subcutaneous heterotopic approach is used to establish urothelial tumor PDX models, reasonably high take-rates can be expected. In a recent systematic review, Bernardo et al. looked at 12 studies using PDX models for urothelial carcinoma with an overall take rate of 41\% [34], which compares favorably to those of generating PDX of prostate cancer or renal cell carcinoma [6,35]. The authors found that Matrigel, a commercially available cell culture matrix consisting of growth factors and extracellular matrix proteins, was also associated with an improved take-rate in bladder tumors. The Matrigel can also serve to prevent the grafted specimen from shifting within the subcutaneous pocket. While some researchers have attempted to utilize mechanical or enzymatic dissociation of the tumor cells followed by subcutaneous injection of a cell suspension, this has not been associated with improved engraftment rates when compared to solid tumor implantation [34].

To date, only six attempts at PDX creation from upper tract urothelial carcinoma (UTUC) have been reported with limited establishment and characterization [36]. As the genomic landscape of urothelial carcinoma is further elucidated, key differences have been identified in tumors of upper tract origin, differentiating them from lower urinary tract bladder cancers with potential biological and clinical implications $[37,38]$. Further work is needed to develop such PDX models.

\section{In Vivo Therapy Response}

\subsection{Comparable Histology}

Xenograft models can only serve as a translational and preclinical platform to accurately predict tumor response to therapies if they preserve histology, gene expression, and tumor mutation profile [18]. While the initial patient tumor histology should be confirmed with a genitourinary pathologist at the time of first engraftment, it is also essential to confirm maintenance of original histological characteristics with each successive passaging of tumor tissue. A small sample of representative tissue should be preserved and carefully examined to confirm malignant histology prior to experimental initiation. Numerous different histologic sub-types of RCC have been successfully grafted from human tumor samples, including conventional clear cell, papillary, translocation, and RCC with sarcomatoid differentiation [19]. Light microscopy evaluation of hematoxylin and eosin (H\&E) stained slides, along with use of immunohistochemical staining can ensure that grafted tumors retain the same pathologic characteristics as the primary tumors. Immunophenotyping with molecular markers expressed by RCC, including carbonic anhydrase IX and CD10 have shown similar expression patterns, indicating successful concordance [33]. Importantly, in orthotopic RCC PDX models, malignant lymphocytes can infiltrate the kidney, mimicking growth of the tumor graft. This underlines the importance of verifying histology with every passage [18].

Following initial engraftment of the tumor into the host, human stroma is present with the malignant tumor cells, but with serial passages this is replaced by murine-derived stroma. When the endothelial cells, fibroblast, and other stromal elements known to affect cancer progression or inhibition are murine, there may be aberrant cross-reactivity with human-derived tumor cells. This has an impact on interactions with the tumor microenvironment, including alteration of paracrine signaling or murine cytokine reactivity. This limits the ability to examine therapies that target the tumor microenvironment in the PDX models and complicates the interpretation of drug response $[39,40]$.

\subsection{Retained Molecular Characteristics}

It is essential that the PDX model recapitulates not only the phenotypic or histological characteristics of the in-situ disease, but that the genomic and transcriptomic alterations are maintained in the PDX model after engraftment and multiple passages. Testing of the somatic mutational profile of the PDX for concordance with the original tissue can ensure the fidelity of the engrafted tumor and its response to targeted therapies. While earlier studies sought to confirm the preservation of tumor identity with immunohistochemical staining, developments in next-generation sequencing (NGS) have lowered costs and allow researchers to evaluate passaged tumors to ensure concordance with parental tumor 
identity. More rapid testing with NGS yield results within weeks. Pan et al. demonstrated through whole-exome and transcriptome sequencing that their PDX model of bladder cancer shared 92-97\% of the genetic aberrations of the parental tumor. This allowed them to identify druggable targets, such as FGFR3, to serve as targets of molecularly guided therapies. Such high fidelity, with preservation of the parental tumor genetic aberrations through serial passages, is extremely important to ensure translational applicability of observed treatment responses [41].

It has been shown that with serial passages, patient-derived cancer cell-lines will acquire DNA copy-number alterations that deviate from the parental tumor. This has been seen in RCC models as well $[42,43]$. Similarly, it is known that PDX models have the ability to acquire additional genomic mutations with subsequent passages. This has been observed across a variety of cancer types, including urothelial and renal cell carcinomas. PDX tumors can show divergent copy-number alteration (CNA) profiles from the parental tumor, suggesting different selection pressures altering the genomic profile of the PDX tumors. The potential impact of genetic drift should be considered with experimental design [44]. Retaining parental mutational profiles is particularly important with the development of therapies targeting patient tumors that harbor specific driver mutations. When pre-clinical validation of efficacy is dependent on genomic stability of the PDX model with serial passaging, it is prudent to systematically confirm the fidelity of the molecular profile.

Molecular subtyping of both bladder cancer and RCC is an area of clinical research with important implications for PDX models. Transcriptional clustering by mRNA expression analysis in bladder cancer can be used to categorize tumors into subtypes with distinct phenotypes. Within these subtypes are luminal, basal/squamous, and neuronal-type tumors. While further validation is needed, there are potential predictive and prognostic implications of molecular subtyping that may eventually guide therapy decisions. As such, it is important that the different subtypes be reflected in PDX models, as there may be clinically significant differences in sensitivity to chemotherapy or targeted therapies. For example, luminal cancers that tend to be enriched in activating mutations in FGFR3 may better respond to FGFR3 inhibiting agents [45].

Analogous to the molecular subtyping in bladder cancer, RCC expression profiles have been evaluated and may have similarly prognostic value. It is similarly imperative that RCC PDX models address differences in treatment responses seen in distinct subgroups identified using transcriptomic profiling [46]. Different molecular subtypes have been extensively correlated with treatment responses to targeted therapies, such as tyrosine kinase inhibitors [47]. Wang et al. used RNA-sequencing data from 35 patient-derived xenograft models to establish an "inflamed pan-RCC subtype." Using a novel dissection algorithm that allowed them to define a tumor microenvironment gene expression signature, their work suggested the putative role of tumor cells in driving the stromal immune response [48].

An important limitation of genomic and transcriptomic sequencing in PDX models is the potential mixing of human and murine genetic content. To correct for this, reads mapping to human genes can be separated from reads mapping to mouse genes.

\subsection{Correlation with Therapy Response and Chemosensitivity}

The well-known limitations of human cancer cell lines have led researchers to search for preclinical cancer models that can reliably predict drug response in human trials. Alternatives to PDX include use of cell-line-derived xenografts, but these are known to lack heterogeneity of the disease in vivo. As discussed, they may acquire additional genetic alterations that lead phenotypic changes not reflected in the parental tumor [19]. PDX models might serve as a more consistent and accurate model of tumor response to treatment, primarily as a result of preserved tumor genomic profile and a more faithful model of intra-tumoral cellular heterogeneity [49]. In translational applications, panels of PDX models can screen for drug efficacy, resistance mechanisms, and aid in identifying biomarkers of predictive of drug sensitivity and response (Table 1). In a large cohort of mice grafted from a heterogeneous population of patient RCC tumors, Schueler et al. found that they were able to predict tumor response to therapy based on HMGB1 levels [50]. 
Table 1. Published studies of targeted anti-neoplastic treatments utilizing novel patient-derived tumor xenografts models in renal cell carcinoma.

\begin{tabular}{|c|c|c|c|c|c|c|}
\hline Study Name & Cancer Type & $\begin{array}{l}\text { PDX Tumor } \\
\text { Models }\end{array}$ & Graft Location & PDX Line & Targets & Drugs/Therapies \\
\hline $\begin{array}{l}\text { Elbanna et al. } \\
\text { (2019) [51] }\end{array}$ & $\begin{array}{l}\text { Clear cell renal cell } \\
\text { carcinoma }\end{array}$ & 3 & $\begin{array}{l}\text { Orthotopic and subcutaneous } \\
\text { heterotopic }\end{array}$ & RP-R-01, RP-R-02, and RP-R02LM & $\begin{array}{l}\text { Angiopoietin } 1 / 2, \\
\text { MET kinase }\end{array}$ & $\begin{array}{c}\text { Trebananib (angiopoietin } \\
1 / 2 \text { inhibitor), MET kinase } \\
\text { inhibitor }\end{array}$ \\
\hline $\begin{array}{l}\text { Schueler et al. } \\
\text { (2018) [50] }\end{array}$ & $\begin{array}{l}\text { Clear cell, papillary, } \\
\text { chromophobe renal } \\
\text { cell carcinoma }\end{array}$ & 44 & Subcutaneous heterotopic & $\begin{array}{c}\text { Institutional: University Hospital } \\
\text { Frankfurt }\end{array}$ & $\begin{array}{c}\text { VEGF, } \\
\text { VHL-associated } \\
\text { targets, mTOR }\end{array}$ & $\begin{array}{c}\text { Sunitinib, pazopanib, } \\
\text { sorafenib, axitinib, } \\
\text { temsirolimus, bevacizumab }\end{array}$ \\
\hline $\begin{array}{l}\text { Adelaiye-Ogala } \\
\text { et al. (2018) [52] }\end{array}$ & $\begin{array}{l}\text { Clear cell renal cell } \\
\text { carcinoma }\end{array}$ & 2 & Subcutaneous heterotopic & RP-R-02LM, 786-O & $\begin{array}{l}\text { Androgen receptor, } \\
\text { receptor tyrosine } \\
\text { kinase }\end{array}$ & Enzalutamide, sunitinib \\
\hline $\begin{array}{l}\text { Damayanti et al. } \\
\text { (2018) [53] }\end{array}$ & $\begin{array}{l}\text { Translocation renal } \\
\text { cell carcinoma }\end{array}$ & 1 & Subcutaneous heterotopic & RP-R07 & $\begin{array}{l}\mathrm{PI} 3 \mathrm{~K} / \mathrm{AKT} / \mathrm{mTOR} \\
\text { pathways }\end{array}$ & $\begin{array}{l}\text { Rapamycin, MLN0128 } \\
\text { (mTOR inhibitor), BEZ-235 } \\
\text { (PI3K inhibitor) }\end{array}$ \\
\hline $\begin{array}{l}\text { Zhao et al. } \\
\text { (2017) [54] }\end{array}$ & $\begin{array}{l}\text { Papillary renal cell } \\
\text { carcinoma }\end{array}$ & 1 & $\begin{array}{l}\text { Orthotopic and subcutaneous } \\
\text { heterotopic }\end{array}$ & Institutional tumor & MET & Cabozantinib \\
\hline $\begin{array}{l}\text { Adelaiye-Ogala } \\
\text { et al. (2017) [55] }\end{array}$ & $\begin{array}{l}\text { Clear cell renal cell } \\
\text { carcinoma }\end{array}$ & 2 & $\begin{array}{c}\text { Ectopic in prostate } \\
\text { (metastatic model), } \\
\text { Orthotopic, and } \\
\text { Subcutaneous heterotopic }\end{array}$ & RP-R-01, RP-R-02, and RP-R02LM & EZH2, VEGF & $\begin{array}{l}\text { HKT288, sunitinib, axitinib, } \\
\text { bevacizumab }\end{array}$ \\
\hline $\begin{array}{l}\text { Bialucha et al. } \\
\text { (2017) [56] }\end{array}$ & $\begin{array}{l}\text { Clear cell renal cell } \\
\text { Carcinoma }\end{array}$ & 3 & Subcutaneous heterotopic & $\begin{array}{l}\text { Multiple institutional tumors, } \\
\text { commercial vendors }\end{array}$ & $\mathrm{CDH} 6$ & $\begin{array}{l}\text { HKT288 (anti-CDH6 } \\
\text { antibody drug conjugate) }\end{array}$ \\
\hline $\begin{array}{l}\text { Dong et al. } \\
(2017)[57]\end{array}$ & Renal cell Carcinoma & 33 & Subcutaneous heterotopic & $\begin{array}{l}\text { Institutional: Memorial Sloan } \\
\text { Kettering Cancer Center (New York) }\end{array}$ & $\begin{array}{l}\text { Receptor tyrosine } \\
\text { kinase }\end{array}$ & Sunitinib \\
\hline $\begin{array}{l}\text { Hong et al. } \\
(2017)[58]\end{array}$ & Renal cell Carcinoma & 2 & Subcutaneous heterotopic & $\begin{array}{l}\text { Institutional: Peking University } \\
\text { Hospital (Peking) }\end{array}$ & $\begin{array}{l}\text { PDGFA, PDGFB, } \\
\text { PDGFRA }\end{array}$ & $\begin{array}{l}\text { Sorafenib, sunitinib, } \\
\text { axitinib }\end{array}$ \\
\hline $\begin{array}{l}\text { Chen et al. } \\
\text { (2016) [59] }\end{array}$ & Renal cell carcinoma & 22 & Orthotopic & $\begin{array}{l}\text { Institutional: UT Southwestern } \\
\text { (Dallas, TX) }\end{array}$ & HIF-2 & $\begin{array}{c}\text { PT2399 (HIF-2 antagonist), } \\
\text { sunitinib }\end{array}$ \\
\hline $\begin{array}{l}\text { Diaz-Montero } \\
\text { et al. (2016) [60] }\end{array}$ & Renal cell carcinoma & 2 & Subcutaneous heterotopic & $\begin{array}{l}\text { Institutional: Cleveland Clinic } \\
\text { (Cleveland, } \mathrm{OH})\end{array}$ & MEK1/2 & $\begin{array}{l}\text { Sunitinib, PD-0325901 } \\
\text { (MEK inhibitor) }\end{array}$ \\
\hline $\begin{array}{l}\text { Lang et al. } \\
\text { (2016) [61] }\end{array}$ & Renal cell carcinoma & 30 & $\begin{array}{l}\text { Orthotopic and } \\
\text { Subcutaneous heterotopic }\end{array}$ & $\begin{array}{l}\text { Institutional: Hôpitaux } \\
\text { Universitaires de Strasbourg (France) }\end{array}$ & $\begin{array}{l}\text { VHL-associated } \\
\text { targets }\end{array}$ & $\begin{array}{l}\text { Sunitinib, sorafenib, } \\
\text { everolimus }\end{array}$ \\
\hline
\end{tabular}


Table 1. Cont.

\begin{tabular}{|c|c|c|c|c|c|c|}
\hline Study Name & Cancer Type & $\begin{array}{l}\text { PDX Tumor } \\
\text { Models }\end{array}$ & Graft Location & PDX Line & Targets & Drugs/Therapies \\
\hline $\begin{array}{l}\text { Adelaiye et al. } \\
\text { (2015) [62] }\end{array}$ & $\begin{array}{l}\text { Clear cell renal cell } \\
\text { carcinoma }\end{array}$ & 2 & Subcutaneous heterotopic & RP-R-01 and RP-R-02 & $\begin{array}{l}\text { Receptor tyrosine } \\
\text { kinase }\end{array}$ & Sunitinib \\
\hline $\begin{array}{l}\text { Ciamporcero } \\
\text { et al. (2015) [63] }\end{array}$ & Renal cell carcinoma & 1 & Subcutaneous heterotopic & RP-R-01 & $\begin{array}{l}\text { VEGF and HGF/c-met } \\
\text { pathway }\end{array}$ & $\begin{array}{l}\text { Axitinib, crizotinib, } \\
\text { sunitinib }\end{array}$ \\
\hline $\begin{array}{l}\text { Schuller et al. } \\
\text { (2015) [64] }\end{array}$ & $\begin{array}{l}\text { Papillary renal cell } \\
\text { carcinoma }\end{array}$ & 2 & Subcutaneous heterotopic & RCC $-43 b$ and RCC-47 PRCC & MET & Savolitinib, sunitinib \\
\hline $\begin{array}{l}\text { Miles et al. } \\
\text { (2014) [65] }\end{array}$ & $\begin{array}{l}\text { Clear cell renal cell } \\
\text { carcinoma }\end{array}$ & 2 & Subcutaneous heterotopic & RP-R-01 and RP-R-02 & DII4, VEGF, & $\begin{array}{l}\text { REGN (mAb binding DII4) } \\
\text { ziv-aflibercept (VEGF } \\
\text { blocker), sunitinib }\end{array}$ \\
\hline $\begin{array}{l}\text { Thong et al. } \\
\text { (2014) [23] }\end{array}$ & Renal cell carcinoma & 13 & Orthotopic & $\begin{array}{l}\text { Institutional: Stanford Hospital } \\
\text { (Stanford, CA) }\end{array}$ & $\begin{array}{l}\text { Receptor tyrosine } \\
\text { kinase }\end{array}$ & Sunitinib \\
\hline $\begin{array}{l}\text { Ingels et al. } \\
(2014)[66]\end{array}$ & Renal cell carcinoma & 3 & Orthotopic & $\begin{array}{l}\text { Institutional: Stanford } \\
\text { (Stanford, CA) }\end{array}$ & mTOR & $\begin{array}{c}\text { MLN0128 (mTOR } \\
\text { inhibitor), temsirolimus }\end{array}$ \\
\hline $\begin{array}{l}\text { Sivanand et al. } \\
\text { (2012) [32] }\end{array}$ & Renal Cell Carcinoma & 35 & Orthotopic & $\begin{array}{l}\text { Institutional: UT Southwestern } \\
\text { (Dallas, TX) }\end{array}$ & $\begin{array}{l}\text { VHL-associated } \\
\text { targets }\end{array}$ & $\begin{array}{l}\text { Dovitinib, sirolimus, } \\
\text { sunitinib }\end{array}$ \\
\hline $\begin{array}{l}\text { Karam et al. } \\
\text { (2011) [67] }\end{array}$ & Renal cell carcinoma & 4 & $\begin{array}{c}\text { Orthotopic and } \\
\text { Subcutaneous heterotopic }\end{array}$ & $\begin{array}{l}\text { Institutional: MD Anderson Cancer } \\
\text { Center (Houston, TX) }\end{array}$ & $\begin{array}{l}\text { VHL-associated } \\
\text { targets }\end{array}$ & Sunitinib, everolimus \\
\hline $\begin{array}{l}\text { Hammers et al. } \\
\text { (2010) [68] }\end{array}$ & Renal cell carcinoma & 1 & Subcutaneous heterotopic & $\begin{array}{l}\text { Institutional: Johns Hopkins } \\
\text { (Baltimore, MD) }\end{array}$ & $\begin{array}{l}\text { Receptor tyrosine } \\
\text { kinase }\end{array}$ & Sunitinib \\
\hline
\end{tabular}


Traditional systemic chemotherapies have been notoriously ineffective against advanced renal cell carcinoma. As such, targeted therapies in RCC have become essential in the management of the disease when it has spread beyond the clinically localized setting. Numerous pathways including $\mathrm{VEGF}_{1-3}, \mathrm{mTOR}_{\mathrm{PDGFR} \alpha}, \mathrm{MET}, \mathrm{FGFR}_{1-4}, \mathrm{RET}, \mathrm{KIT}$, and AXL have been targeted by established and emerging therapies [12]. Various agents have been tested in the pre-clinical setting using PDX models to investigate tumor response. Importantly, it has been shown that PDX models for RCC can better correlate with clinical response to sunitinib than cancer cell lines [57]. In one of the largest studies to date, Sivavand et al. performed validation of targeted therapies in 94 different RCC patient tumor samples, 35 of which yielded viable tumor xenografts, and 16 were able to be serially passed successfully. Both histologic and genomic features were preserved in the xenograft models, allowing for testing of sensitivity to different targeted systemic therapies including sunitinib, sirolimus, and erlotinib [32].

In the treatment of urothelial cancers, platinum-based neoadjuvant chemotherapy (NAC) followed by radical cystectomy is the standard of care for muscle-invasive bladder cancer. While NAC has been associated with a pathologic response in $40 \%$ of patients with a complete response in up to $25 \%$, there is significant overtreatment of non-responders [69]. The exposure to toxic agents without apparent benefit presents an opportunity to improve patient selection. Russell et al. demonstrated in their PDX model the heterogeneity of tumor response to these therapies, recapitulating the varied resistance seen in clinical practice [70]. With the recent addition of pembrolizumab, atezolizumab and other immune checkpoint inhibitors to the armamentarium of anti-neoplastic agents for urothelial carcinoma, there is a potential role for PDX models to serve as "mouse avatars," allowing clinicians to determine platinum sensitivity and thus guide initial therapy choice in both the neoadjuvant and advanced settings. A number of published studies have sought to evaluate anti-neoplastic agents in urothelial carcinoma (Table 2).

At this time, approved therapy options targeting specific genes or biomarkers are limited in urothelial cancer. Erdafitinib, a tyrosine kinase inhibitor of fibroblast growth factor receptor (FGFR), was recently approved as the first targeted systemic therapy for metastatic urothelial cancer in patients with known FGFR2/3 mutations [71]. While no xenograft models have evaluated this drug, Pan et al. evaluated infigratinib (BGJ398), a similar selective pan-FGFR antagonist using bladder cancer PDX models. In addition, they evaluated other targeted treatments including EGFR/HER2 dual inhibitor lapatinib and PIK3CA inhibitor BEZ235, finding variable efficacy [41]. Jager et al. similarly evaluated FGFR3 inhibition using a monoclonal antibody in PDX models [72].

\subsection{Future Directions}

In the future, select patients with high-risk, clinically localized disease may be potential candidates for personalized PDX models. Tumor samples can be collected at the time of radical cystectomy (for urothelial carcinoma) or nephrectomy (for RCC) to establish xenograft models. The PDX model can then be used to screen both standard therapies and drugs targeting specific molecular aberrations in the patient's tumor. If the patient presents with disease recurrence, which typically takes several months, drugs with proven efficacy in the PDX models can be administered to the patient. Further studies demonstrating correlation between PDX response and patient parental tumor response are needed to validate such an approach. Furthermore, the cost of such as system has thus far prevented such integration into clinical practice. A more realistic approach is to generate PDX libraries with representative tumor subtypes and mutational variants. A focus on models that have been under-represented in cell lines would better reflecting the intertumoral heterogeneity of RCC and urothelial cancer. Once a library is established, specific targeted therapies can be screened for efficacy and resistance mechanisms. 
Table 2. Published studies of targeted anti-neoplastic treatments utilizing novel patient-derived tumor xenografts models in urothelial cell carcinoma.

\begin{tabular}{|c|c|c|c|c|c|c|}
\hline Study Name & Cancer Type & $\begin{array}{l}\text { PDX Tumor } \\
\text { Models }\end{array}$ & Graft Location & PDX Line & Target & Drug/Therapy \\
\hline $\begin{array}{l}\text { Blinova et al. } \\
\text { (2019) [73] }\end{array}$ & $\begin{array}{l}\text { Urothelial cell } \\
\text { carcinoma }\end{array}$ & 6 & $\begin{array}{l}\text { Subcutaneous } \\
\text { heterotopic }\end{array}$ & $\begin{array}{l}\text { Institutional: National Research Medical } \\
\text { Center of Radiology (Moscow) }\end{array}$ & PD-L1 & Durvalumab \\
\hline $\begin{array}{l}\text { Zeng et al. } \\
\text { (2017) [74] }\end{array}$ & $\begin{array}{l}\text { Urothelial cell } \\
\text { carcinoma }\end{array}$ & 3 & $\begin{array}{l}\text { Subcutaneous } \\
\text { heterotopic }\end{array}$ & $\begin{array}{l}\text { BL0269, BL0293, BL0440 (UC Davis/Jackson } \\
\text { Labs) }\end{array}$ & PI3K pathway & $\begin{array}{l}\text { Pictilisib, Cisplatin, } \\
\text { gemcitabine }\end{array}$ \\
\hline $\begin{array}{l}\text { Ler et al. } \\
(2017)[75]\end{array}$ & $\begin{array}{l}\text { Urothelial cell } \\
\text { carcinoma }\end{array}$ & Not reported & $\begin{array}{l}\text { Subcutaneous } \\
\text { heterotopic }\end{array}$ & $\begin{array}{l}\text { Institutional: Singapore General Hospital } \\
\text { (Singapore) and Chang Gung Memorial } \\
\text { Hospital (Taiwan) }\end{array}$ & EZH2 & $\begin{array}{l}\text { GSK503 (EZH2 } \\
\text { methyltransferase } \\
\text { inhibitor) }\end{array}$ \\
\hline $\begin{array}{l}\text { Wei et al. } \\
\text { (2016) [76] }\end{array}$ & $\begin{array}{l}\text { Urothelial cell } \\
\text { carcinoma }\end{array}$ & 2 & $\begin{array}{l}\text { Subcutaneous } \\
\text { heterotopic }\end{array}$ & $\begin{array}{l}\text { Institutional: Roswell Park BLCAb001, } \\
\text { BLCAb002 }\end{array}$ & PI3K/mTOR & $\begin{array}{l}\text { Cisplatin, LY414 (dual } \\
\text { PI3K/mTOR inhibitor) }\end{array}$ \\
\hline $\begin{array}{l}\text { Chang et al. } \\
\text { (2016) [77] }\end{array}$ & $\begin{array}{l}\text { Urothelial cell } \\
\text { carcinoma }\end{array}$ & 1 & $\begin{array}{l}\text { Subcutaneous } \\
\text { heterotopic }\end{array}$ & $\begin{array}{l}\text { Institutional: Samsung Medical Center } \\
\text { (Seoul) }\end{array}$ & $\begin{array}{c}\text { SRC and } \\
\text { PI3K/AKT/mTOR }\end{array}$ & $\begin{array}{l}\text { Dasatinib, PKI-587 (dual } \\
\text { PI3K/mTOR inhibitor) }\end{array}$ \\
\hline $\begin{array}{l}\text { Pan et al. } \\
\text { (2016) [78] }\end{array}$ & $\begin{array}{l}\text { Urothelial cell } \\
\text { carcinoma }\end{array}$ & 1 & $\begin{array}{l}\text { Subcutaneous } \\
\text { heterotopic }\end{array}$ & Institutional (UC Davis) & $\begin{array}{l}\text { Bladder cancer cells } \\
\text { (PLZ4 ligand) }\end{array}$ & $\begin{array}{l}\text { Disulfide-crosslinked } \\
\text { PLZ4-nanomicelle } \\
\text { paclitaxel }\end{array}$ \\
\hline $\begin{array}{l}\text { Ciamporcero } \\
\text { et al. (2016) [79] }\end{array}$ & $\begin{array}{l}\text { Urothelial cell } \\
\text { carcinoma }\end{array}$ & 2 & $\begin{array}{l}\text { Subcutaneous } \\
\text { heterotopic }\end{array}$ & $\begin{array}{l}\text { Institutional: Roswell Park BLCAb001, } \\
\text { BLCAb002 }\end{array}$ & $\begin{array}{l}\text { YAP (Yes-associated } \\
\text { protein) }\end{array}$ & Verteporfin, cisplatin \\
\hline $\begin{array}{l}\text { Guo et al. } \\
\text { (2016) [80] }\end{array}$ & $\begin{array}{l}\text { Urothelial cell } \\
\text { carcinoma }\end{array}$ & 1 & $\begin{array}{l}\text { Subcutaneous } \\
\text { heterotopic }\end{array}$ & $\begin{array}{l}\text { Institutional: Shanghai Changhai Hospital } \\
\text { (Shanghai) }\end{array}$ & $\begin{array}{l}\text { HuR RNA-binding } \\
\text { protein }\end{array}$ & $\begin{array}{l}\text { Pyrvinium pamoate } \\
\text { combined with cisplatin }\end{array}$ \\
\hline $\begin{array}{l}\text { Jager et al. } \\
\text { (2015) [72] }\end{array}$ & $\begin{array}{l}\text { Urothelial cell } \\
\text { carcinoma }\end{array}$ & 7 & Renal subcapsular & $\begin{array}{l}\text { Institutional: Vancouver General Hospital } \\
\text { (Vancouver, Canada) }\end{array}$ & FGFR3 & $\begin{array}{l}\text { R3Mab (anti-FGFR3 } \\
\text { antibody) }\end{array}$ \\
\hline $\begin{array}{l}\text { Pan et al. } \\
\text { (2015) [41] }\end{array}$ & $\begin{array}{l}\text { Urothelial cell } \\
\text { carcinoma }\end{array}$ & 22 & $\begin{array}{l}\text { Orthotopic and } \\
\text { Subcutaneous } \\
\text { heterotopic }\end{array}$ & $\begin{array}{l}\text { Institutional: UC Davis (including } \\
\text { PDX-BL0293, PDX-BL0382) }\end{array}$ & $\begin{array}{l}\text { EGFR/HER2, PIK3CA, } \\
\text { FGFR3 }\end{array}$ & $\begin{array}{c}\text { Lapatinib, ponatinib, } \\
\text { BEZ235 (PI3K/mTOR } \\
\text { inhibitor), BGJ398 (FGFR } \\
\text { inhibitor) }\end{array}$ \\
\hline $\begin{array}{l}\text { Cirone et al. } \\
\text { (2014) [3] }\end{array}$ & $\begin{array}{l}\text { Urothelial cell } \\
\text { carcinoma }\end{array}$ & 2 & $\begin{array}{l}\text { Subcutaneous } \\
\text { heterotopic }\end{array}$ & $\begin{array}{l}\text { Commercial: PDX-BL0293, PDX-BL0382 } \\
\text { (UC Davis/Jackson Labs) }\end{array}$ & PI3K/mTOR, MEK & $\begin{array}{c}\text { PF-502 (PI3K/mTOR } \\
\text { inhibitor), PD-901 (MEK } \\
\text { inhibitor) }\end{array}$ \\
\hline $\begin{array}{l}\text { Abe et al. } \\
(2006)[36]\end{array}$ & $\begin{array}{l}\text { Urothelial cell } \\
\text { carcinoma }\end{array}$ & 15 & $\begin{array}{l}\text { Subcutaneous } \\
\text { heterotopic }\end{array}$ & Institutional: Hokkaido University Hospital & $\mathrm{n} / \mathrm{a}$ & Radiation \\
\hline
\end{tabular}




\section{Limitations}

An understanding of the limitations of PDX models is essential for appropriate experimental design. When compared to traditional cancer cell lines, PDX models are costly and require substantial technical expertise. They can also be time consuming, with slow-growing tumors requiring months for successful engraftment.

\subsection{Immunotherapy Testing}

Immuno-oncology is an exciting and rapidly evolving field, particularly with the treatment of advanced bladder and kidney cancers. This therapeutic revolution has seen the recent approval of numerous immune checkpoint inhibitors [12]. Unfortunately, the utilization of immune-deficient mice limits the ability to test therapies that rely on $\mathrm{T}$ cell anti-tumor activity, significantly restricting the applicability of PDX models in the testing of immune checkpoint inhibitors. The development of humanized mice has sought to resolve this significant disadvantage. These mice, also known as human haemato-lymphoid chimeric mice or human immune system models, generate a competent human immune system through various methodologies [40]. This has been an important development in the field, accomplished by irradiating NSG or NOG mice and then transplanting human CD34+ hematopoietic progenitor and stem cells. The mice are considered humanized when over $25 \%$ of the cells in the peripheral blood are hCD34+. These humanized NSG mice can develop a partially functional human immune system, allowing for better characterization of the tumor-immune microenvironment and the testing of immunotherapy drugs. Limited studies have evaluated the efficacy of immunotherapies in bladder cancer cell lines. Wang et al. showed that by using allogeneic, but HLA partially matched CD34+ hematopoietic stem cell donors and tumors (including bladder cancer), immune checkpoint inhibitors can be effectively studied in the humanized mouse PDX model. In their study, the mice did not reject the engrafted tumors and demonstrated the efficacy of pembrolizumab in CD8+ T-cell mediated tumor growth inhibition [81]. Blinova et al. used humanized NSG mice to test PDL-1 blocker durvalumab and demonstrated PDL-1 expression in PDX models with significant stagnation of tumor growth [73]. It is hoped that further development of humanized mouse PDX models will allow for the study of the interaction of the tumor and the human immune system, as early models suggest that both therapeutic outcomes and side effects can be recapitulated [82].

\subsection{Xenotropic Murine-Derived Viral Infection}

It is important for any researcher working with patient-derived xenografts or patient-derived cell lines to be aware of the potentially confounding effect that xenotropic murine retroviruses (XMRV) can have on growth parameters. There are reports of xenotropic murine leukemia viruses (MLVs) that are activated in immunodeficient mice with passage of human tissue. Though initially thought to play a causal role in the oncogenesis of prostate cancer, this has since been debunked. However, xenotropic viruses such as MLV, when activated, can induce spontaneous tumor formation in mice. It is suspected that there is relatively high prevalence of xenotropic viral infection in PDX models, with one study reporting detection of xenotropic endogenous murine leukemia virus in up to $53 \%$ of human breast cancer PDXs. Though the effect of XMRVs specifically on growth of kidney and urothelial tumors is unknown, PCR should be used to detect activated virus if there is any clinical suspicion. Periodic monitoring for XMRVs can also be done if there is concern for contamination. This also emphasizes the importance of sterile technique with tumor passaging to prevent widespread viral contamination of PDX models or cell lines in the lab [83-85].

\subsection{Intratumoral Heterogeneity}

The intertumoral heterogeneity that is seen in clinical practice is not reflected in genetically engineered mouse models, which tend to develop more homogeneous tumors. Tumor grafts are derived from a small area of the parental tumor, and thus fail to fully capture the heterogeneity of the 
entire tumor. Sampling multiple areas of the tumor for grafting can better capture the intra-tumoral heterogeneity that is known to be present in both bladder cancer and RCC, but this remains a limitation of any pre-clinical model.

\section{Alternative Patient-Derived Models: Organoids}

Building on experience with patient-derived cell lines, the utilization of patient-derived organoids (PDO) provides a less expensive alternative to solid tumor xenograft models. Organoids are three-dimensional tissue cultures and can be successfully established using human tumor cells. Lee et al. described 22 patient-derived bladder cancer organoid lines, and they successfully converted these lines into orthotopic xenografts using ultrasound-guided implantation. They demonstrated the ability to efficiently interconvert organoids and xenograft models in urothelial carcinoma [86]. Furthermore, they found high concordance of molecular profiles in the organoid and xenograft models with the parental tumors and were able to validate drug responses in vivo. As a result of the identified interconvertibility, they proposed a model of disease treatment in which patients have drug responses identified in PDOs, which can then be validated in PDX models prior to guiding patient therapies. Similarly, Mullenders et al. established a biobank of patient-derived urothelial tumor organoids that showed basal and luminal cells and were able to use them as predictors of chemotherapy response. Their high efficiency of human bladder cancer organoid generation allowed for extensive experimentation and the potential for novel drug screening [87]. Clearly, there will be a continued important role for patient-derived organoids to be used in conjunction with patient-derived xenografts in development of targeted therapies.

\section{Conclusions}

While no single in vivo system fully recapitulates the complexity of human cancers, combined pre-clinical approaches that include patient-derived xenografts are a growing and important component for research in urothelial and renal cell carcinomas. With the expanding number of both therapeutic drugs and better characterization of rational targets in urologic malignancies, the role for PDX models in elucidating susceptibilities and mechanisms of treatment resistance is expanding. Advancements in technical efficiency, improved understanding of limitations, and clinical validation of PDX models in bladder and renal malignancies will allow for improved translational application.

Author Contributions: Conceptualization, K.S.M. and K.K.; writing-original draft preparation, A.T.T.; writing-review and editing, A.T.T., K.S.M., J.A.C. and K.K.; visualization, K.K.; supervision, J.A.C. and K.K.; project administration, J.A.C. and K.K. All authors have read and agreed to the published version of the manuscript.

Funding: Funded in part through the NIH/NCI Cancer Center Support Grant P30 CA008748.

Conflicts of Interest: The authors declare no conflict of interest.

\section{Abbreviations}

$\begin{array}{ll}\text { NSG } & \text { NOD (NOD.Cg-Prkdcscid Il2rgtm1Wjl/SzJ) scid gamma } \\ \text { NAC } & \text { neoadjuvant chemotherapy } \\ \text { PDX } & \text { patient-derived xenograft } \\ \text { RCC } & \text { renal cell carcinoma } \\ \text { Scid } & \text { severe-combined immune deficiency } \\ \text { UTUC } & \text { upper tract urothelial carcinoma }\end{array}$

\section{References}

1. Tentler, J.J.; Tan, A.C.; Weekes, C.D.; Jimeno, A.; Leong, S.; Pitts, T.M.; Arcaroli, J.J.; Messersmith, W.A.; Eckhardt, S.G. Patient-derived tumour xenografts as models for oncology drug development. Nat. Rev. Clin. Oncol. 2012, 9, 338-350. [CrossRef] [PubMed] 
2. Hidalgo, M.; Amant, F.; Biankin, A.V.; Budinska, E.; Byrne, A.T.; Caldas, C.; Clarke, R.B.; de Jong, S.; Jonkers, J.; Maelandsmo, G.M.; et al. Patient-derived xenograft models: An emerging platform for translational cancer research. Cancer Discov. 2014, 4, 998-1013. [CrossRef] [PubMed]

3. Cirone, P.; Andresen, C.J.; Eswaraka, J.R.; Lappin, P.B.; Bagi, C.M. Patient-derived xenografts reveal limits to PI3K/mTOR- and MEK-mediated inhibition of bladder cancer. Cancer Chemother. Pharmacol. 2014, 73, 525-538. [CrossRef] [PubMed]

4. Rygaard, J.; Povlsen, C.O. Heterotransplantation of a human malignant tumour to "Nude" mice. Acta Pathol. Microbiol. Scand. 1969, 77, 758-760. [CrossRef] [PubMed]

5. Sufrin, G.; McGarry, M.P.; Sandberg, A.A.; Murphy, G.P. Heterotransplantation of human transitional cell carcinoma in athymic mice. J. Urol. 1979, 121, 159-161. [CrossRef]

6. Naito, S.; Iwakawa, A.; Tanaka, K.; Momose, S.; Hirata, K.; Emoto, K.; Sakamoto, K.; Hara, S. Heterotransplantation of human urinary bladder cancers in nude mice. Investig. Urol. 1981, 18, 285-288.

7. Katsuoka, Y.; Baba, S.; Hata, M.; Tazaki, H. Transplantation of human renal cell carcinoma to the nude mice: As an intermediate of in vivo and in vitro studies. J. Urol. 1976, 115, 373-376. [CrossRef]

8. Siegel, R.L.; Miller, K.D.; Jemal, A. Cancer statistics, 2019. CA Cancer J. Clin. 2019, 69, 7-34. [CrossRef]

9. Dieleman, J.; Campbell, M.; Chapin, A.; Eldrenkamp, E.; Fan, V.Y.; Haakenstad, A.; Kates, J.; Liu, Y.; Matyasz, T.; Micah, A.; et al. Evolution and patterns of global health financing 1995-2014: Development assistance for health, and government, prepaid private, and out-of-pocket health spending in 184 countries. Lancet 2017, 389, 1981-2004. [CrossRef]

10. Prasad, S.M.; Decastro, G.J.; Steinberg, G.D.; Medscape. Urothelial carcinoma of the bladder: Definition, treatment and future efforts. Nat. Rev. Urol. 2011, 8, 631-642. [CrossRef]

11. Berdik, C. Unlocking bladder cancer. Nature 2017, 551, S34-S35. [CrossRef] [PubMed]

12. Zarrabi, K.; Paroya, A.; Wu, S. Emerging therapeutic agents for genitourinary cancers. J. Hematol. Oncol. 2019, 12, 89. [CrossRef] [PubMed]

13. Von der Maase, H.; Hansen, S.W.; Roberts, J.T.; Dogliotti, L.; Oliver, T.; Moore, M.J.; Bodrogi, I.; Albers, P.; Knuth, A.; Lippert, C.M.; et al. Gemcitabine and cisplatin versus methotrexate, vinblastine, doxorubicin, and cisplatin in advanced or metastatic bladder cancer: Results of a large, randomized, multinational, multicenter, phase III study. J. Clin. Oncol. 2000, 18, 3068-3077. [CrossRef]

14. American Cancer Society. Cancer Facts \& Figures; American Cancer Society: Atlanta, GA, USA, 2008.

15. Okada, S.; Vaeteewoottacharn, K.; Kariya, R. Application of Highly Immunocompromised Mice for the Establishment of Patient-Derived Xenograft (PDX) Models. Cells 2019, 8, 889. [CrossRef] [PubMed]

16. Taghian, A.; Budach, W.; Zietman, A.; Freeman, J.; Gioioso, D.; Ruka, W.; Suit, H.D. Quantitative comparison between the transplantability of human and murine tumors into the subcutaneous tissue of $\mathrm{NCr} / \mathrm{Sed}-\mathrm{nu} / \mathrm{nu}$ nude and severe combined immunodeficient mice. Cancer Res. 1993, 53, 5012-5017. [PubMed]

17. Shultz, L.D.; Goodwin, N.; Ishikawa, F.; Hosur, V.; Lyons, B.L.; Greiner, D.L. Human cancer growth and therapy in immunodeficient mouse models. Cold Spring Harb. Protoc. 2014, 2014, 694-708. [CrossRef] [PubMed]

18. Pavia-Jimenez, A.; Tcheuyap, V.T.; Brugarolas, J. Establishing a human renal cell carcinoma tumorgraft platform for preclinical drug testing. Nat. Protoc. 2014, 9, 1848-1859. [CrossRef]

19. Inoue, T.; Terada, N.; Kobayashi, T.; Ogawa, O. Patient-derived xenografts as in vivo models for research in urological malignancies. Nat. Rev. Urol. 2017, 14, 267-283. [CrossRef]

20. Kato, C.; Fujii, E.; Chen, Y.J.; Endaya, B.B.; Matsubara, K.; Suzuki, M.; Ohnishi, Y.; Tamaoki, N. Spontaneous thymic lymphomas in the non-obese diabetic/Shi-scid, IL-2R gamma (null) mouse. Lab. Anim. 2009, 43, 402-404. [CrossRef]

21. Tillman, H.; Janke, L.J.; Funk, A.; Vogel, P.; Rehg, J.E. Morphologic and Immunohistochemical Characterization of Spontaneous Lymphoma/Leukemia in NSG Mice. Vet. Pathol. 2019, 57, 160-171. [CrossRef]

22. Radaelli, E.; Hermans, E.; Omodho, L.; Francis, A.; Vander Borght, S.; Marine, J.C.; van den Oord, J.; Amant, F. Spontaneous Post-Transplant Disorders in NOD.Cg- Prkdcscid Il2rgtm1Sug/JicTac (NOG) Mice Engrafted with Patient-Derived Metastatic Melanomas. PLoS ONE 2015, 10, e0124974. [CrossRef] [PubMed]

23. Thong, A.E.; Zhao, H.; Ingels, A.; Valta, M.P.; Nolley, R.; Santos, J.; Young, S.R.; Peehl, D.M. Tissue slice grafts of human renal cell carcinoma: An authentic preclinical model with high engraftment rate and metastatic potential. Urol. Oncol. 2014, 32, e23-e30. [CrossRef] [PubMed] 
24. Ivanics, T.; Bergquist, J.R.; Liu, G.; Kim, M.P.; Kang, Y.; Katz, M.H.; Perez, M.V.R.; Thomas, R.M.; Fleming, J.B.; Truty, M.J. Patient-derived xenograft cryopreservation and reanimation outcomes are dependent on cryoprotectant type. Lab. Investig. 2018, 98, 947-956. [CrossRef] [PubMed]

25. Porter, L.H.; Lawrence, M.G.; Wang, H.; Clark, A.K.; Bakshi, A.; Obinata, D.; Goode, D.; Papargiris, M.; Clouston, D.; Ryan, A.; et al. Establishing a cryopreservation protocol for patient-derived xenografts of prostate cancer. Prostate 2019, 79, 1326-1337. [CrossRef]

26. Hoffman, R.M. Patient-derived orthotopic xenografts: Better mimic of metastasis than subcutaneous xenografts. Nat. Rev. Cancer 2015, 15, 451-452. [CrossRef]

27. Linxweiler, J.; Korbel, C.; Muller, A.; Jungel, E.; Blaheta, R.; Heinzelmann, J.; Stockle, M.; Junker, K.; Menger, M.D.; Saar, M. Experimental imaging in orthotopic renal cell carcinoma xenograft models: Comparative evaluation of high-resolution 3D ultrasonography, in-vivo micro-CT and 9.4T MRI. Sci. Rep. 2017, 7, 14249. [CrossRef]

28. Lorenzatti Hiles, G.; Cates, A.L.; El-Sawy, L.; Day, K.C.; Broses, L.J.; Han, A.L.; Briggs, H.L.; Emamdjomeh, A.; Chou, A.; Abel, E.V.; et al. A surgical orthotopic approach for studying the invasive progression of human bladder cancer. Nat. Protoc. 2019, 14, 738-755. [CrossRef]

29. Gills, J.; Moret, R.; Zhang, X.; Nelson, J.; Maresh, G.; Hellmers, L.; Canter, D.; Hudson, M.; Halat, S.; Matrana, M.; et al. A patient-derived orthotopic xenograft model enabling human high-grade urothelial cell carcinoma of the bladder tumor implantation, growth, angiogenesis, and metastasis. Oncotarget 2018, 9, 32718-32729. [CrossRef]

30. Chan, E.; Patel, A.; Heston, W.; Larchian, W. Mouse orthotopic models for bladder cancer research. BJU Int. 2009, 104, 1286-1291. [CrossRef]

31. Tatum, J.L.; Kalen, J.D.; Jacobs, P.M.; Ileva, L.V.; Riffle, L.A.; Hollingshead, M.G.; Doroshow, J.H. A spontaneously metastatic model of bladder cancer: Imaging characterization. J. Transl. Med. 2019, 17, 425. [CrossRef]

32. Sivanand, S.; Pena-Llopis, S.; Zhao, H.; Kucejova, B.; Spence, P.; Pavia-Jimenez, A.; Yamasaki, T.; McBride, D.J.; Gillen, J.; Wolff, N.C.; et al. A validated tumorgraft model reveals activity of dovitinib against renal cell carcinoma. Sci. Transl. Med. 2012, 4, 137-175. [CrossRef]

33. Grisanzio, C.; Seeley, A.; Chang, M.; Collins, M.; Di Napoli, A.; Cheng, S.C.; Percy, A.; Beroukhim, R.; Signoretti, S. Orthotopic xenografts of RCC retain histological, immunophenotypic and genetic features of tumours in patients. J. Pathol. 2011, 225, 212-221. [CrossRef]

34. Bernardo, C.; Costa, C.; Sousa, N.; Amado, F.; Santos, L. Patient-derived bladder cancer xenografts: A systematic review. Transl. Res. 2015, 166, 324-331. [CrossRef]

35. Lawrence, M.G.; Taylor, R.A.; Toivanen, R.; Pedersen, J.; Norden, S.; Pook, D.W.; Frydenberg, M.; Papargiris, M.M.; Niranjan, B.; Richards, M.G.; et al. A preclinical xenograft model of prostate cancer using human tumors. Nat. Protoc. 2013, 8, 836-848. [CrossRef]

36. Abe, T.; Tada, M.; Shinohara, N.; Okada, F.; Itoh, T.; Hamada, J.; Harabayashi, T.; Chen, Q.; Moriuchi, T.; Nonomura, K. Establishment and characterization of human urothelial cancer xenografts in severe combined immunodeficient mice. Int. J. Urol. 2006, 13, 47-57. [CrossRef]

37. Sfakianos, J.P.; Cha, E.K.; Iyer, G.; Scott, S.N.; Zabor, E.C.; Shah, R.H.; Ren, Q.; Bagrodia, A.; Kim, P.H.; Hakimi, A.A.; et al. Genomic Characterization of Upper Tract Urothelial Carcinoma. Eur. Urol. 2015, 68, 970-977. [CrossRef]

38. Audenet, F.; Isharwal, S.; Cha, E.K.; Donoghue, M.T.A.; Drill, E.N.; Ostrovnaya, I.; Pietzak, E.J.; Sfakianos, J.P.; Bagrodia, A.; Murugan, P.; et al. Clonal Relatedness and Mutational Differences between Upper Tract and Bladder Urothelial Carcinoma. Clin. Cancer Res. 2019, 25, 967-976. [CrossRef]

39. Gengenbacher, N.; Singhal, M.; Augustin, H.G. Preclinical mouse solid tumour models: Status quo, challenges and perspectives. Nat. Rev. Cancer 2017, 17, 751-765. [CrossRef]

40. Byrne, A.T.; Alferez, D.G.; Amant, F.; Annibali, D.; Arribas, J.; Biankin, A.V.; Bruna, A.; Budinska, E.; Caldas, C.; Chang, D.K.; et al. Interrogating open issues in cancer precision medicine with patient-derived xenografts. Nat. Rev. Cancer 2017, 17, 254-268. [CrossRef]

41. Pan, C.X.; Zhang, H.; Tepper, C.G.; Lin, T.Y.; Davis, R.R.; Keck, J.; Ghosh, P.M.; Gill, P.; Airhart, S.; Bult, C.; et al. Development and Characterization of Bladder Cancer Patient-Derived Xenografts for Molecularly Guided Targeted Therapy. PLoS ONE 2015, 10, e0134346. [CrossRef] 
42. Rubio-Viqueira, B.; Hidalgo, M. Direct in vivo xenograft tumor model for predicting chemotherapeutic drug response in cancer patients. Clin. Pharmacol. Ther. 2009, 85, 217-221. [CrossRef] [PubMed]

43. Daniel, V.C.; Marchionni, L.; Hierman, J.S.; Rhodes, J.T.; Devereux, W.L.; Rudin, C.M.; Yung, R.; Parmigiani, G.; Dorsch, M.; Peacock, C.D.; et al. A primary xenograft model of small-cell lung cancer reveals irreversible changes in gene expression imposed by culture in vitro. Cancer Res. 2009, 69, 3364-3373. [CrossRef] [PubMed]

44. Ben-David, U.; Ha, G.; Tseng, Y.Y.; Greenwald, N.F.; Oh, C.; Shih, J.; McFarland, J.M.; Wong, B.; Boehm, J.S.; Beroukhim, R.; et al. Patient-derived xenografts undergo mouse-specific tumor evolution. Nat. Genet. 2017, 49, 1567-1575. [CrossRef]

45. Robertson, A.G.; Kim, J.; Al-Ahmadie, H.; Bellmunt, J.; Guo, G.; Cherniack, A.D.; Hinoue, T.; Laird, P.W.; Hoadley, K.A.; Akbani, R.; et al. Comprehensive Molecular Characterization of Muscle-Invasive Bladder Cancer. Cell 2017, 171, 540-556. [CrossRef]

46. Hakimi, A.A.; Voss, M.H.; Kuo, F.; Sanchez, A.; Liu, M.; Nixon, B.G.; Vuong, L.; Ostrovnaya, I.; Chen, Y.B.; Reuter, V.; et al. Transcriptomic Profiling of the Tumor Microenvironment Reveals Distinct Subgroups of Clear Cell Renal Cell Cancer: Data from a Randomized Phase III Trial. Cancer Discov. 2019, 9, 510-525. [CrossRef]

47. Beuselinck, B.; Job, S.; Becht, E.; Karadimou, A.; Verkarre, V.; Couchy, G.; Giraldo, N.; Rioux-Leclercq, N.; Molinie, V.; Sibony, M.; et al. Molecular subtypes of clear cell renal cell carcinoma are associated with sunitinib response in the metastatic setting. Clin. Cancer Res. 2015, 21, 1329-1339. [CrossRef]

48. Wang, T.; Lu, R.; Kapur, P.; Jaiswal, B.S.; Hannan, R.; Zhang, Z.; Pedrosa, I.; Luke, J.J.; Zhang, H.; Goldstein, L.D.; et al. An Empirical Approach Leveraging Tumorgrafts to Dissect the Tumor Microenvironment in Renal Cell Carcinoma Identifies Missing Link to Prognostic Inflammatory Factors. Cancer Discov. 2018, 8, 1142-1155. [CrossRef]

49. Patel, A.; Cohen, S.; Moret, R.; Maresh, G.; Gobe, G.C.; Li, L. Patient-derived xenograft models to optimize kidney cancer therapies. Transl. Androl. Urol. 2019, 8, S156-S165. [CrossRef]

50. Schueler, J.; Klingner, K.; Bug, D.; Zoeller, C.; Maier, A.; Dong, M.; Willecke, K.; Peille, A.L.; Steiner, E.; Landesfeind, M.; et al. Patient derived renal cell carcinoma xenografts exhibit distinct sensitivity patterns in response to antiangiogenic therapy and constitute a suitable tool for biomarker development. Oncotarget 2018, 9, 30946-30961. [CrossRef]

51. Elbanna, M.; Orillion, A.R.; Damayanti, N.P.; Adelaiye-Ogala, R.; Shen, L.; Miles, K.M.; Chintala, S.; Ciamporcero, E.; Ramakrishnan, S.; Ku, S.Y.; et al. Dual inhibition of angiopoietin-TIE2 and MET alters the tumor microenvironment and prolongs survival in a metastatic model of renal cell carcinoma. Mol. Cancer Ther. 2019. [CrossRef]

52. Adelaiye-Ogala, R.; Damayanti, N.P.; Orillion, A.R.; Arisa, S.; Chintala, S.; Titus, M.A.; Kao, C.; Pili, R. Therapeutic Targeting of Sunitinib-Induced AR Phosphorylation in Renal Cell Carcinoma. Cancer Res. 2018, 78, 2886-2896. [CrossRef] [PubMed]

53. Damayanti, N.P.; Budka, J.A.; Khella, H.W.Z.; Ferris, M.W.; Ku, S.Y.; Kauffman, E.; Wood, A.C.; Ahmed, K.; Chintala, V.N.; Adelaiye-Ogala, R.; et al. Therapeutic Targeting of TFE3/IRS-1/PI3K/mTOR Axis in Translocation Renal Cell Carcinoma. Clin. Cancer Res. 2018, 24, 5977-5989. [CrossRef] [PubMed]

54. Zhao, H.; Nolley, R.; Chan, A.M.W.; Rankin, E.B.; Peehl, D.M. Cabozantinib inhibits tumor growth and metastasis of a patient-derived xenograft model of papillary renal cell carcinoma with MET mutation. Cancer Biol. Ther. 2017, 18, 863-871. [CrossRef] [PubMed]

55. Adelaiye-Ogala, R.; Budka, J.; Damayanti, N.P.; Arrington, J.; Ferris, M.; Hsu, C.C.; Chintala, S.; Orillion, A.; Miles, K.M.; Shen, L.; et al. EZH2 Modifies Sunitinib Resistance in Renal Cell Carcinoma by Kinome Reprogramming. Cancer Res. 2017, 77, 6651-6666. [CrossRef] [PubMed]

56. Bialucha, C.U.; Collins, S.D.; Li, X.; Saxena, P.; Zhang, X.; Durr, C.; Lafont, B.; Prieur, P.; Shim, Y.; Mosher, R.; et al. Discovery and Optimization of HKT288, a Cadherin-6-Targeting ADC for the Treatment of Ovarian and Renal Cancers. Cancer Discov. 2017, 7, 1030-1045. [CrossRef] [PubMed]

57. Dong, Y.; Manley, B.J.; Becerra, M.F.; Redzematovic, A.; Casuscelli, J.; Tennenbaum, D.M.; Reznik, E.; Han, S.; Benfante, N.; Chen, Y.B.; et al. Tumor Xenografts of Human Clear Cell Renal Cell Carcinoma But Not Corresponding Cell Lines Recapitulate Clinical Response to Sunitinib: Feasibility of Using Biopsy Samples. Eur. Urol. Focus 2017, 3, 590-598. [CrossRef]

58. Hong, B.; Yang, Y.; Guo, S.; Duoerkun, S.; Deng, X.; Chen, D.; Yu, S.; Qian, W.; Li, Q.; Li, Q.; et al. Intra-tumour molecular heterogeneity of clear cell renal cell carcinoma reveals the diversity of the response to targeted therapies using patient-derived xenograft models. Oncotarget 2017, 8, 49839-49850. [CrossRef] 
59. Chen, W.; Hill, H.; Christie, A.; Kim, M.S.; Holloman, E.; Pavia-Jimenez, A.; Homayoun, F.; Ma, Y.; Patel, N.; Yell, P.; et al. Targeting renal cell carcinoma with a HIF-2 antagonist. Nature 2016, 539, 112-117. [CrossRef]

60. Diaz-Montero, C.M.; Mao, F.J.; Barnard, J.; Parker, Y.; Zamanian-Daryoush, M.; Pink, J.J.; Finke, J.H.; Rini, B.I.; Lindner, D.J. MEK inhibition abrogates sunitinib resistance in a renal cell carcinoma patient-derived xenograft model. Br. J. Cancer 2016, 115, 920-928. [CrossRef]

61. Lang, H.; Beraud, C.; Bethry, A.; Danilin, S.; Lindner, V.; Coquard, C.; Rothhut, S.; Massfelder, T. Establishment of a large panel of patient-derived preclinical models of human renal cell carcinoma. Oncotarget 2016, 7 , 59336-59359. [CrossRef]

62. Adelaiye, R.; Ciamporcero, E.; Miles, K.M.; Sotomayor, P.; Bard, J.; Tsompana, M.; Conroy, D.; Shen, L.; Ramakrishnan, S.; Ku, S.Y.; et al. Sunitinib dose escalation overcomes transient resistance in clear cell renal cell carcinoma and is associated with epigenetic modifications. Mol. Cancer Ther. 2015, 14, 513-522. [CrossRef]

63. Ciamporcero, E.; Miles, K.M.; Adelaiye, R.; Ramakrishnan, S.; Shen, L.; Ku, S.; Pizzimenti, S.; Sennino, B.; Barrera, G.; Pili, R. Combination strategy targeting VEGF and HGF/c-met in human renal cell carcinoma models. Mol. Cancer Ther. 2015, 14, 101-110. [CrossRef] [PubMed]

64. Schuller, A.G.; Barry, E.R.; Jones, R.D.; Henry, R.E.; Frigault, M.M.; Beran, G.; Linsenmayer, D.; Hattersley, M.; Smith, A.; Wilson, J.; et al. The MET Inhibitor AZD6094 (Savolitinib, HMPL-504) Induces Regression in Papillary Renal Cell Carcinoma Patient-Derived Xenograft Models. Clin. Cancer Res. 2015, 21, 2811-2819. [CrossRef] [PubMed]

65. Miles, K.M.; Seshadri, M.; Ciamporcero, E.; Adelaiye, R.; Gillard, B.; Sotomayor, P.; Attwood, K.; Shen, L.; Conroy, D.; Kuhnert, F.; et al. Dll4 blockade potentiates the anti-tumor effects of VEGF inhibition in renal cell carcinoma patient-derived xenografts. PLoS ONE 2014, 9, e112371. [CrossRef] [PubMed]

66. Ingels, A.; Zhao, H.; Thong, A.E.; Saar, M.; Valta, M.P.; Nolley, R.; Santos, J.; Peehl, D.M. Preclinical trial of a new dual mTOR inhibitor, MLN0128, using renal cell carcinoma tumorgrafts. Int. J. Cancer 2014, 134, 2322-2329. [CrossRef] [PubMed]

67. Karam, J.A.; Zhang, X.Y.; Tamboli, P.; Margulis, V.; Wang, H.; Abel, E.J.; Culp, S.H.; Wood, C.G. Development and characterization of clinically relevant tumor models from patients with renal cell carcinoma. Eur. Urol. 2011, 59, 619-628. [CrossRef]

68. Hammers, H.J.; Verheul, H.M.; Salumbides, B.; Sharma, R.; Rudek, M.; Jaspers, J.; Shah, P.; Ellis, L.; Shen, L.; Paesante, S.; et al. Reversible epithelial to mesenchymal transition and acquired resistance to sunitinib in patients with renal cell carcinoma: Evidence from a xenograft study. Mol. Cancer Ther. 2010, 9, 1525-1535. [CrossRef]

69. Zargar, H.; Espiritu, P.N.; Fairey, A.S.; Mertens, L.S.; Dinney, C.P.; Mir, M.C.; Krabbe, L.M.; Cookson, M.S.; Jacobsen, N.E.; Gandhi, N.M.; et al. Multicenter assessment of neoadjuvant chemotherapy for muscle-invasive bladder cancer. Eur. Urol. 2015, 67, 241-249. [CrossRef]

70. Russell, P.J.; Raghavan, D.; Gregory, P.; Philips, J.; Wills, E.J.; Jelbart, M.; Wass, J.; Zbroja, R.A.; Vincent, P.C. Bladder cancer xenografts: A model of tumor cell heterogeneity. Cancer Res. 1986, 46, 2035-2040.

71. Loriot, Y.; Necchi, A.; Park, S.H.; Garcia-Donas, J.; Huddart, R.; Burgess, E.; Fleming, M.; Rezazadeh, A.; Mellado, B.; Varlamov, S.; et al. Erdafitinib in Locally Advanced or Metastatic Urothelial Carcinoma. N. Engl. J. Med. 2019, 381, 338-348. [CrossRef]

72. Jager, W.; Xue, H.; Hayashi, T.; Janssen, C.; Awrey, S.; Wyatt, A.W.; Anderson, S.; Moskalev, I.; Haegert, A.; Alshalalfa, M.; et al. Patient-derived bladder cancer xenografts in the preclinical development of novel targeted therapies. Oncotarget 2015, 6, 21522-21532. [CrossRef]

73. Blinova, E.; Roshchin, D.; Kogan, E.; Samishina, E.; Demura, T.; Deryabina, O.; Suslova, I.; Blinov, D.; Zhdanov, P.; Osmanov, U.; et al. Patient-Derived Non-Muscular Invasive Bladder Cancer Xenografts of Main Molecular Subtypes of the Tumor for Anti-Pd-11 Treatment Assessment. Cells 2019, 8, 526. [CrossRef]

74. Zeng, S.X.; Zhu, Y.; Ma, A.H.; Yu, W.; Zhang, H.; Lin, T.Y.; Shi, W.; Tepper, C.G.; Henderson, P.T.; Airhart, S.; et al. The Phosphatidylinositol 3-Kinase Pathway as a Potential Therapeutic Target in Bladder Cancer. Clin. Cancer Res. 2017, 23, 6580-6591. [CrossRef] [PubMed]

75. Ler, L.D.; Ghosh, S.; Chai, X.; Thike, A.A.; Heng, H.L.; Siew, E.Y.; Dey, S.; Koh, L.K.; Lim, J.Q.; Lim, W.K.; et al. Loss of tumor suppressor KDM6A amplifies PRC2-regulated transcriptional repression in bladder cancer and can be targeted through inhibition of EZH2. Sci. Transl. Med. 2017, 9. [CrossRef] [PubMed] 
76. Wei, L.; Chintala, S.; Ciamporcero, E.; Ramakrishnan, S.; Elbanna, M.; Wang, J.; Hu, Q.; Glenn, S.T.; Murakami, M.; Liu, L.; et al. Genomic profiling is predictive of response to cisplatin treatment but not to PI3K inhibition in bladder cancer patient-derived xenografts. Oncotarget 2016, 7, 76374-76389. [CrossRef] [PubMed]

77. Chang, N.; Lee, H.W.; Lim, J.E.; Jeong, D.E.; Song, H.J.; Kim, S.; Nam, D.H.; Sung, H.H.; Jeong, B.C.; Seo, S.I.; et al. Establishment and antitumor effects of dasatinib and PKI-587 in BD-138T, a patient-derived muscle invasive bladder cancer preclinical platform with concomitant EGFR amplification and PTEN deletion. Oncotarget 2016, 7, 51626-51639. [CrossRef] [PubMed]

78. Pan, A.; Zhang, H.; Li, Y.; Lin, T.Y.; Wang, F.; Lee, J.; Cheng, M.; Dall'Era, M.; Li, T.; deVere White, R.; et al. Disulfide-crosslinked nanomicelles confer cancer-specific drug delivery and improve efficacy of paclitaxel in bladder cancer. Nanotechnology 2016, 27, 425103. [CrossRef]

79. Ciamporcero, E.; Shen, H.; Ramakrishnan, S.; Yu Ku, S.; Chintala, S.; Shen, L.; Adelaiye, R.; Miles, K.M.; Ullio, C.; Pizzimenti, S.; et al. YAP activation protects urothelial cell carcinoma from treatment-induced DNA damage. Oncogene 2016, 35, 1541-1553. [CrossRef]

80. Guo, J.; Lv, J.; Chang, S.; Chen, Z.; Lu, W.; Xu, C.; Liu, M.; Pang, X. Inhibiting cytoplasmic accumulation of HuR synergizes genotoxic agents in urothelial carcinoma of the bladder. Oncotarget 2016, 7, 45249-45262. [CrossRef]

81. Wang, M.; Yao, L.C.; Cheng, M.; Cai, D.; Martinek, J.; Pan, C.X.; Shi, W.; Ma, A.H.; De Vere White, R.W.; Airhart, S.; et al. Humanized mice in studying efficacy and mechanisms of PD-1-targeted cancer immunotherapy. FASEB J. 2018, 32, 1537-1549. [CrossRef]

82. Chen, Q.; Wang, J.; Liu, W.N.; Zhao, Y. Cancer Immunotherapies and Humanized Mouse Drug Testing Platforms. Transl. Oncol. 2019, 12, 987-995. [CrossRef] [PubMed]

83. Arias, M.; Fan, H. The saga of XMRV: A virus that infects human cells but is not a human virus. Emerg. Microbes Infect. 2014, 3. [CrossRef] [PubMed]

84. Naseer, A.; Terry, A.; Gilroy, K.; Kilbey, A.; Watts, C.; Mackay, N.; Bell, M.; Mason, S.; Blyth, K.; Cameron, E.; et al. Frequent infection of human cancer xenografts with murine endogenous retroviruses in vivo. Viruses 2015, 7, 2014-2029. [CrossRef]

85. Bock, S.; Mullins, C.S.; Klar, E.; Perot, P.; Maletzki, C.; Linnebacher, M. Murine Endogenous Retroviruses Are Detectable in Patient-Derived Xenografts but Not in Patient-Individual Cell Lines of Human Colorectal Cancer. Front. Microbiol. 2018, 9, 789. [CrossRef] [PubMed]

86. Lee, S.H.; Hu, W.; Matulay, J.T.; Silva, M.V.; Owczarek, T.B.; Kim, K.; Chua, C.W.; Barlow, L.J.; Kandoth, C.; Williams, A.B.; et al. Tumor Evolution and Drug Response in Patient-Derived Organoid Models of Bladder Cancer. Cell 2018, 173, 515-528.e17. [CrossRef] [PubMed]

87. Mullenders, J.; de Jongh, E.; Brousali, A.; Roosen, M.; Blom, J.P.A.; Begthel, H.; Korving, J.; Jonges, T.; Kranenburg, O.; Meijer, R.; et al. Mouse and human urothelial cancer organoids: A tool for bladder cancer research. Proc. Natl. Acad. Sci. USA 2019, 116, 4567-4574. [CrossRef]

(C) 2020 by the authors. Licensee MDPI, Basel, Switzerland. This article is an open access article distributed under the terms and conditions of the Creative Commons Attribution (CC BY) license (http://creativecommons.org/licenses/by/4.0/). 